\title{
Becoming Local
}

Datuk Kong beliefs in Sarawak, East Malaysia

\section{Elena Gregoria Chai Chin Fern \& Monica Janowski}

To cite this article: Elena Gregoria Chai Chin Fern \& Monica Janowski (2022): Becoming Local, Indonesia and the Malay World, DOI: 10.1080/13639811.2022.2018830

To link to this article: https://doi.org/10.1080/13639811.2022.2018830

曲 Published online: 04 Feb 2022.

Submit your article to this journal 전

Q View related articles $\longleftarrow$

View Crossmark data $\asymp$ 


\title{
BECOMING LOCAL Datuk Kong beliefs in Sarawak, East Malaysia
}

\author{
Elena Gregoria Chai Chin Fern and Monica Janowski
}

\begin{abstract}
Datuk Kong (拿督公) are shen (神) - a Chinese term that can be glossed in English as 'deity' or 'spirit' depending on context. They have long been known to be venerated by Chinese in West Malaysia but have not been investigated until now in Sarawak, where they are of increasing importance, or in Kalimantan, where they appear to have been worshipped for much longer. In both West Malaysia and in Borneo Datuk Kong are closely associated with (a) the ethnic groups that were already living in the area before the Chinese arrived and (b) with the local landscape. In this article we explore the ways in which Datuk Kong beliefs have developed in Borneo and how, through the 'respect' (拜) paid to these shen, the Chinese have integrated the beliefs that they brought originally from China into a belief system that remains distinctively Chinese but overlaps with the beliefs of ethnic groups with which they co-exist; and embedded this belief system in the local landscape and the spirits inhabiting that landscape.
\end{abstract}

\section{KEYWORDS}

Datuk Kong; Tua Pek Kong; Chinese folk religion; Sarawak; East Malaysia

\section{Introduction}

In this article we will present beliefs and practices related to the shen (deity/spirit) Datuk Kong (Chinese: 拿督公; Na Tuk Kong ${ }^{1}$ ) in Sarawak. ${ }^{2}$ We relate these to practices and beliefs associated with another shen, Tua Pek Kong ${ }^{3}$ (大伯公), and also to those related to shen Tu Di Kong (拿督公), the soil deity. We argue that these practices and beliefs reflect a process whereby Chinese in Sarawak have responded to the local natural and cosmological environment in a way that has integrated them into that environment.

The material presented here was gathered through fieldwork carried out by one of the authors, Elena Chai. Between 2013 and 2019, Chai carried out fieldwork in Sarawak on Tua Pek Kong temples, including an extensive survey in 2013 (Chai 2014a). Many of these include altars to Datuk Kong. Chai is a Sarawakian Chinese herself and can draw on additional understanding and knowledge based on this. She also carried out fieldwork in West Kalimantan from July to November 2016 as part of a research collaboration with the Beijing Foreign Studies University, with another research visit between

CONTACT Monica Janowski monica.janowski@gmail.com

${ }^{1}$ This is a transliteration of the Mandarin version of the name of this shen.

${ }^{2}$ We use the transliteration Kong in this article for 公 as this is the one most commonly used in Sarawak. Some publications use the pinyin form, Gong.

${ }^{3}$ This is a transliteration of the Hokkien version of the name of this shen.

(C) 2022 Editors, Indonesia and the Malay World 